\title{
Correction
}

\section{Correction to: Process system analysis on oil processing facility and economic viability from oil well-to-tank}

\author{
Bilal kazmi ${ }^{1}$ Syed Ali Ammar Taqvi ${ }^{2} \cdot$ Muhammad Naqvi $^{3}$ - Suhaib Umer llyas ${ }^{4} \cdot$ Ali Moshin $^{5} \cdot$ Farah Inamullah $^{1}$. \\ Salman R. Naqvi ${ }^{6}$
}

Published online: 11 January 2022

(O) The Author(s) 2022 OPEN

\section{Correction to: SN Applied Sciences (2021) 3:682 https://doi.org/10.1007/s42452-021-04635-z}

In this article the second author was incorrectly shown with a second affiliation. The original article has been corrected.

Open Access This article is licensed under a Creative Commons Attribution 4.0 International License, which permits use, sharing, adaptation, distribution and reproduction in any medium or format, as long as you give appropriate credit to the original author(s) and the source, provide a link to the Creative Commons licence, and indicate if changes were made. The images or other third party material in this article are included in the article's Creative Commons licence, unless indicated otherwise in a credit line to the material. If material is not included in the article's Creative Commons licence and your intended use is not permitted by statutory regulation or exceeds the permitted use, you will need to obtain permission directly from the copyright holder. To view a copy of this licence, visit http://creativecommons. org/licenses/by/4.0/.

Publisher's Note Springer Nature remains neutral with regard to jurisdictional claims in published maps and institutional affiliations.

The original article can be found online at https://doi.org/10.1007/s42452-021-04635-z.

Muhammad Naqvi, raza.naqvi@kau.se | 'Department of Applied Chemistry and Chemical Technology, University of Karachi, Karachi, Pakistan. ${ }^{2}$ Department of Chemical Engineering, NED University of Engineering and Technology, Karachi, Pakistan. ${ }^{3}$ Department of Engineering and Chemical Sciences, Karlstad University, Karlstad, Sweden. ${ }^{4}$ Institute of Hydrocarbon Recovery, Universiti Teknologi PETRONAS, 32610 Seri Iskandar, Perak Darul Ridzuan, Malaysia. ${ }^{5}$ Technical University of Crete, Chania, Greece. ${ }^{6}$ School of Chemical and Material Engineering, National University of Sciences \& Technology, Islamabad, Pakistan. 